"Experimental measurement of carbohydrate-aromatic stacking in water by using a dangling-ended DNA model system”. Morales, J.C., Reina, J.J., Díaz, I., Aviñó, A., Nieto, P.M., Eritja, R. Chemistry Eur. J., 14(26), 7828-7835 (2008). doi: 10.1002/chem.200800335

\title{
Experimental measurement of carbohydrate-aromatic stacking in water by using a dangling-ended DNA model system
}

Juan C. Morales ${ }^{\mathrm{a}^{*}}$, José J. Reina ${ }^{\mathrm{a}}$, Irene Díaz ${ }^{\mathrm{a}}$, Anna Aviñó ${ }^{\mathrm{b}}$, Pedro Nieto ${ }^{\mathrm{a}}$, Ramón Eritja ${ }^{\mathrm{b}}$

${ }^{a}$ Instituto de Investigaciones Químicas, CSIC - Universidad de Sevilla, 49 Americo Vespucio, 41092 Sevilla, Spain

${ }^{\mathrm{b}}$ Institute for Research in Biomedicine, Barcelona Science Park, IBMB - CSIC, CIBER BBN Networking Centre on Bioengineering, Biomaterials and Nanomedicine, Josep Samitier 1, E-08028 Barcelona, Spain

*Corresponding author: (telephone 34-954-489-561; fax 34-954-460-565; e-mail: jcmorales@iiq.csic.es). 
Abstract: Protein-carbohydrate recognition is of fundamental importance for a large number of biological processes; carbohydrate-aromatic stacking is a widespread, but poorly understood, structural motif in this recognition. We describe, for the first time, the measurement of carbohydrate-aromatic interactions from their contribution to the stability of a dangling-ended DNA model system. We observe clear differences in the energetics of the interactions of several monosaccharides with a benzene moiety depending on the number of hydroxy groups, the stereochemistry, and the presence of a methyl group in the pyranose ring. A fucose-benzene pair is the most stabilizing of the studied series $(-0.4$ Kcal $\mathrm{mol}^{-1}$ ) and this interaction can be placed in the same range as other more studied interactions with aromatic residues of proteins, such as Phe-Phe, Phe-Met, or Phe-His. The noncovalent forces involved seem to be dispersion forces and nonconventional hydrogen bonds, whereas hydrophobic effects do not seem to drive the interaction.

Keywords: carbohydrate-aromatic stacking; carbohydrates; DNA; molecular recognition; stacking interactions

\section{INTRODUCTION}

Protein-carbohydrate interactions play a fundamental role within the living organisms in processes such as apoptosis, infection, inflammation, or fertilization.[1] Among the most cited noncovalent forces that participate in carbohydrate-protein recognition are hydrogenbonding and ionic interactions. The role of water has also been mentioned to be a determinant driving force in this process.[2] In addition, a widespread, but poorly 
understood, structural motif found between carbohydrates and proteins is the stacking of apolar patches of oligosaccharides with aromatic residues,[3] in which different noncovalent forces have been suggested to play a role, namely, $\mathrm{CH}-\pi$ interactions, Van der Waals forces, and hydrophobic effects.[4] Studies into carbohydrate-aromatic stacking interactions have been approached by using molecular biology tools,[5] NMR spectroscopy,[3b, 6] IR spectroscopy,[7] computational methods,[4a-c, 8] and model systems.[9] Artificial receptors that incorporate aromatics in their structure and take advantage of stacking interactions for carbohydrate recognition in apolar solvents have been reported.[10] Recently, a receptor containing meta-terphenyl units has been shown to bind cellobiose derivatives selectively in water.[11]

Nevertheless, few experimental binding data on sugar- arene stacking interactions have been reported and the quantification of these interactions has been attempted only in two specific examples. The interaction of a glucose-tyrosine pair as a transition-state stabilization was measured to be $0.7 \mathrm{kcalmol}^{-1}$ in the -IV subsite of a 1,3-1,4- $\beta$-D-glucan4-glucanohydrolase system, in which cooperativity could be playing a role.[12] Recently, a nonbiologically relevant tetraacetylglucose- tryptophan interaction was found to stabilize a hairpin-peptide model system by $0.8 \mathrm{kcalmol}^{-1}$.[13]

Herein, we describe the first model system in which carbohydrate- aromatic stacking interactions are measured and systematically studied. To do so, we quantified the contribution of two sugar-arene pairs to the stability of a dangling-ended DNA system. The energetic contributions of monosaccharide-benzene pairs in our DNA model system range from -0.15 to $-0.40 \mathrm{kcalmol}^{-1}$. The observed differences are due to the influence of the number of hydroxy groups, the stereochemistry, and the presence of a methyl group in the 
pyranose ring. An upfield chemical shift of the NMR signals of all sugar protons in the oligonucleotide-carbohydrate conjugates confirmed the proximity of the carbohydrate to the face of the arene ring.

\section{Results and Discussion}

Design of the DNA model system: Our design of a dangling-ended DNA model is inspired by studies of aromatic stacking in DNA in which natural[14] or non-natural nucleosides[15] were placed at the end of a duplex in a "dangling" position. The resulting stabilization of the duplex was measured and compared with the duplex lacking the added nucleotides.

Our model system consists of a "dangling" benzene nucleoside with a covalently bound monosaccharide placed at the 5'-ends of a DNA duplex (Scheme 1A). The sugar is linked through an ethylene glycol spacer to a phosphate group located on the primary hydroxy group of the benzene nucleoside. This allows the pyranose ring to be on top of the benzene ring because it will be apart from the phosphate by the same distance as that found in a nucleoside between the base and its corresponding phosphate group (Scheme 1B). At the same time, this spacer allows enough freedom for the sugar to be either immersed in bulk water or in contact with the benzene ring. The DNA double helix acts as an energetic probe that allows the carbohy-drate-aromatic interaction to be quantified when the carbohydrateoligonucleotide conjugate is compared with the control lacking the carbohydrate moiety. In addition, the conjugate will allow the incorporation of different non-natural aromatic nucleosides and monosaccharides to quantify the interaction.

Synthesis of the carbohydrate-oligonucleotide conjugates: Preparation of the carbohydrate-oligonucleotide conjugates (COCs, 1-7; Scheme 1C) was carried out by 
standard solid-phase oligonucleotide automatic synthesis by using the DMTphosphoramidite benzene nucleoside[16] and the corresponding carbohydrate phosphoramidite (DMT: 4,4'di-methoxytriphenylmethyl). $\quad \beta$-D-Glucose, $\quad \beta$-D-2deoxyglucose, $\alpha$-D-2-deoxyglucose, $\beta$-D-galactose, and $\beta$-L-fucose were the monosaccharides selected to study how the interaction with a benzene ring is affected by different factors, such as the number of hydroxy groups, the anomeric configuration, the stereochemistry of the pyranose ring, and the presence of a methyl group.

The synthesis of the carbohydrate phosphoramidites was carried out in two steps. First, in the case of glucose, galactose, and fucose, attachment of the ethylene glycol spacer to the carbohydrate was carried out by classical glycosidation chemistry with the peracetylated bromo monosaccharides to obtain only the corresponding $\beta$ isomers (Scheme 2). 2Hydroxyethyl- 2,3,4,6-tetra- $O$-acetyl- $\beta$-D-glucopyranoside (14) and 2-hydroxyethyl2,3,4,6-tetra- $O$-acetyl- $\beta$-D-galactopyranoside (17) were prepared as described previously,[17] and 2-hydroxyethyl-2,3,4-tri- $O$-acetyl- $\beta$-L-fucopyranoside (20) was synthesized following the same methodology. The 2-deoxyglucose derivatives were prepared by electrophilic addition to the corresponding acetyl-protected glucal and subsequent separation of the $\mathrm{a}$ and $\mathrm{b}$ isomers by column chromatography.[18] The corresponding carbohydrate phosphoramidites were then prepared by standard phosphoramidite chemistry (Scheme 2).[19]

Finally, the monosaccharide controls (8-12, Scheme 1C), used for structural comparison with the carbohydrate-oligonucleotide conjugates, were prepared in high yield by deprotection of the corresponding acetylated derivatives $(\mathbf{1 4}, \mathbf{1 7}, \mathbf{2 0}, \mathbf{2 3}$, and 24) by classical methanolysis. 
Thermodynamic parameters of the carbohydrate-DNA model systems: The measured thermodynamic parameters for the carbohydrate-oligonucleotide conjugates under physiological conditions (140 $\mathrm{mm} \mathrm{NaCl}, 20 \mathrm{~mm} \mathrm{KCl,} 10 \mathrm{~mm}$ phosphate buffer, $\mathrm{pH} 7)$ are illustrated in Table 1. The thermodynamic parameters were calculated from the average values obtained from melting curve fitting and linear plots of $1 / T_{m}$ versus $\ln$ [conjugate].[20] Calculation of the contribution of the carbohydrate-aromatic interaction to DNA stabilization was carried out by comparison of the corresponding carbohydrate-DNA conjugate with the control that lacks the pyranose ring but still maintains the ethylene glycol spacer (second row in Table 1). In fact, the presence of the linker destabilizes the DNA conjugate, most probably due to the entropy cost because of its high mobility, and this factor must be taken into account.

The thermodynamic data show that all of the conjugates that contain a carbohydratearomatic moiety show higher stability than the control conjugate $\mathbf{2}$, most probably due to the affinity of the monosaccharides to stack with the benzene ring. It is important to note that the interaction is enthalpy driven, which seems to indicate the minor significance of classical hydrophobic effects in the interaction. Actually, the glucose-benzene interaction showed a stabilization of $-0.25 \mathrm{kcalmol}^{-1}$ in our dangling-ended DNA system.

Next, we investigated the effect of the number of hydroxyl groups in the pyranose ring on the interaction. $\beta$-Glucose stacks more strongly on the benzene ring than $\beta$-2-deoxyglucose, a more hydrophobic sugar that lacks the hydroxyl group at the 2-position. This result seems to support the fact that dispersion forces and nonconventional hydrogen bonds are the main noncovalent forces involved in this interaction, because the proton at the 2-position may be less polarized in $\beta$-2-deoxyglucose and, therefore, the interaction may lose one of the 
nonconventional hydrogen bonds.[4a] When 2-deoxyglucose is attached in the a-anomeric configuration, the stacking is similar to that found for b-2-deoxyglucose. This result could indicate a similar stacking geometry with the aromatic moiety due to the high flexibility of the spacer, but the different chemical shifts of the NMR signals of the sugar protons seem to point to different approaches to the benzene ring (see the structural features section below).

The effect of the stereochemistry of the carbohydrate on the interaction was examined by comparison of $\beta$-glucose and $\beta$-galactose in their interactions with benzene. Surprisingly, the results show that stacking is stronger for glucose than for galactose, although a more extended apolar area in galactose could lead to the opposite result being predicted, especially if dispersion forces are involved in the interaction. A possible reason for this result could be that the ethylene glycol spacer is not long enough to allow the galactose moiety to adopt a more apical geometry and interact with the arene ring through the apolar patch formed by its H3-5 protons. Actually, the chemical-induced shifts of the NMR signals for the protons, obtained by comparing the sugar unit in conjugate 4 with the $\beta$ galactose control 9, indicate a higher population of parallel-stacking geometry between the carbohydrate and the aromatic ring (see the structural features section below). In addition, it should be pointed out that the monosaccharides can approach the benzene unit through both faces of the pyranose ring due to the high flexibility of the linker. A stacking interaction with a parallel geometry between the $\beta$ face of galactose and the aromatic ring is not possible due to the axial configuration of the hydroxyl group in the 4-position and, consequently, the potential contribution to the stability due to contacts through that face is lost in galactose but not in glucose (Figure 1). 
It is important to note that the energetic data obtained refer to differences in stability between carbohydrate-DNA conjugates but these energetic values are an average of the different conformations available for each carbohydrate- DNA conjugate. Furthermore, the possibility of formation of a hydrogen bond between the 4-OH group of glucose and the arene moiety cannot be ruled out; this interaction is not possible in galactose without disrupting the parallel stacking with benzene, due to its intrinsic geometry. Similar reasoning should also be considered when comparing $\beta$-glucose and $\beta$-2-deoxyglucose. Actually, an $\mathrm{H}-$ bond between a glucose $4-\mathrm{OH}$ group and toluene has been observed in the gas phase by IR spectroscopy,[7] and similar H-bonds have been observed in the X-ray crystal structures of proteins, such as between the hydroxy group of Thr13 and the center of the arene ring of Tyr6 in a class $\mu$ glutathione transferase.[21]

Finally, we studied the relevance of a methyl group in the structure of the pyranose ring. The contribution to DNA stabilization of the fucose-benzene interaction is $-0.40 \mathrm{kcal} \mathrm{mol}^{-1}$, which makes this pair the most stable of the series. This carbohydrate-aromatic interaction is in the same range as other more studied interactions with aromatic residues of proteins, such as Phe-Phe, Phe-Met, or Phe-His.[22] The presence of the methyl group considerably increases the apolar surface of the carbohydrate and, therefore, dispersion forces involved in the interaction may be favored.

Structural features of the carbohydrate-aromatic stacking: ${ }^{1} \mathrm{D}$ and ${ }^{2} \mathrm{D}$ NMR experiments were carried out to study the geometry of the dangling moiety of the carbohydrate-oligonucleotide conjugates. We compared the chemical shifts of the resonances of the sugar protons in the carbohydrate-oligonucleotide conjugates (3-7) with those of the corresponding monosaccharide controls $(\mathbf{8}-\mathbf{1 2})$ that possess the linker moiety 
but not the benzene nucleoside or the DNA strand. The comparison of the chemical shifts of the DNA resonances along the series of carbohydrate-oligonucleotide conjugates indicates no structural changes in the nucleic acid fragment. We observed that all of the proton resonances of the pyranose ring in the carbohydrate-oligonucleotide conjugates exhibited upfield shifting relative to those of the corresponding carbohydrate controls (Table 2). Comparison of the ${ }^{1} \mathrm{H}$ NMR spectrum of carbohydrate conjugate $\mathbf{5}$, which contains the $\beta$-L-fucose unit, with that of the $\beta$-L-fucose control $\mathbf{1 0}$ clearly shows the upfield shift observed for all of the protons in the carbohydrate moiety (Figure 2). These data seem to confirm that all of the monosaccharides in the study prefer to stay close to the arene ring rather than just being immersed in the bulk water molecules. The proximity of the monosaccharides to the face of the arene ring could explain the extra stability found in the carbohydrate-oligonucleotide conjugates due to the presence of a potential carbohydrate-aromatic stacking interaction.

Moreover, the monosaccharides can approach the benzene unit through both faces of the pyranose ring, probably due to the high flexibility of the linker. It is important to note that the chemical-induced shifts show a similar trend in the four sugars linked to the DNA conjugate through a $\beta$-anomeric configuration. Upfield shift is more significant on the $\alpha$ face of the pyranose moiety, where protons $\mathrm{H} 1, \mathrm{H} 3$, and $\mathrm{H} 5$ are pointing down, as can be observed, for example, in $\beta$-glucose (Figure 3 ). This seems to indicate a more favourable interaction of the $\beta$-linked monosaccharides with the benzene ring through their $\alpha$ face. Actually, a similar geometric tendency has been found by Waters and co-workers between $\beta$-glucose and tryptophan in a $\beta$-hairpin-peptide model.[13] 
In contrast to the results for sugars linked through a $\beta$-anomeric configuration to the DNA conjugate, the chemical-induced shifts for a-2-deoxyglucose show similar magnitude on both sides of the pyranose moiety. This could suggest that this sugar approaches the arene ring in a different way to the $\beta$-2-deoxyglucose and, therefore, different conformations are present during stacking with the aromatic moiety.

Finally, the $\beta$-2-deoxyglucose unit shows the largest resonance shifts of the series, even larger than those for $\beta$-L-fucose. This result is surprising since the stability measured is higher for $\beta$-L-fucose than for $\beta$-2-deoxyglucose during the interaction with benzene. This point to the fact that closer contact of $\beta$-2-deoxyglucose with the benzene ring may be possible due to the lack of a hydroxy group at the 2- position but this does not translate into a more favourable interaction.

\section{Conclusion}

Our results indicate that a dangling-ended DNA model system is a useful tool to measure carbohydrate-aromatic stacking interactions. Clear differences have been observed in the energetics of the interaction depending on the number of hydroxy groups, the stereochemistry, and the presence of a methyl group in the pyranose ring. The noncovalent forces involved seem to be dispersion forces and nonconventional hydrogen bonds between the protons of the pyranose ring and the benzene ring, whereas classical hydrophobic effects do not seem to drive the interaction. Investigations into the influence of other aromatic rings in the interaction and NMR spectroscopy and molecular modelling studies are in progress to obtain a better understanding of carbohydrate-aromatic stacking interactions by using our dangling-ended DNA model system. 


\section{Experimental Section}

General remarks: All chemicals were obtained from Aldrich Chemicals and used without further purification, unless otherwise noted. All reactions were monitored by TLC on precoated silica gel $60 \mathrm{~F}_{254}$ plates (Merck), with detection by heating with Mostain (10\% $\left.\mathrm{H}_{2} \mathrm{SO}_{4}(500 \mathrm{~mL}),\left(\mathrm{NH}_{4}\right)_{6} \mathrm{Mo}_{7} \mathrm{O}_{24} \cdot 4 \mathrm{H}_{2} \mathrm{O}(25 \mathrm{~g}), \mathrm{Ce}\left(\mathrm{SO}_{4}\right)_{2} \cdot 4 \mathrm{H}_{2} \mathrm{O}(1 \mathrm{~g})\right)$. Products were purified by flash chromatography with Merck silica gel 60 (200-400 mesh). Highresolution FAB (+) mass spectral analyses were obtained on a Micromass AutoSpec-Q spectrometer.

NMR spectra were recorded on Bruker AVANCE 300, ARX 400, or Advance DRX 500 $\mathrm{MHz}$ spectrometers $\left(300\right.$ or $400 \mathrm{MHz}\left({ }^{1} \mathrm{H}\right), 75$ or $100\left({ }^{13} \mathrm{C}\right) ; 500 \mathrm{MHz}$ for the carbohydrate controls and for the carbohydrate- DNA conjugate samples) at room temperature for solutions in $\mathrm{CDCl}_{3}, \mathrm{D}_{2} \mathrm{O}$, or $\mathrm{CD}_{3} \mathrm{OD}$. Chemical shifts were referenced to the solvent signal. 2D experiments (COSY, TOCSY, ROESY, and HMQC) were done when necessary to assign resonances of the oligosaccharides or the carbohydrate-DNA conjugates. The carbohydrate-DNA samples for NMR spectroscopy were purified by HPLC and then ionexchanged with Dowex 50W resin. Finally, samples were lyophilized to dryness three times from $\mathrm{D}_{2} \mathrm{O}$ to deuterate all exchangeable protons and dissolved in $99.999 \% \mathrm{D}_{2} \mathrm{O}$ just prior to recording of the NMR spectra. Sample concentration ranged from 0.7 to $2.8 \mathrm{mM}$ depending on the conjugate. Chemical shifts $(\delta)$ are given in ppm with respect to the acetone signal, which was used as an external reference (volume of $1 \mu \mathrm{L}$ ). In all experiments, the ${ }^{1} \mathrm{H}$ carrier frequency was kept at the water resonance. Data were processed by using the 
manufacturer software, raw data were multiplied by a shifted exponential window function prior to Fourier transformation, and the baseline was corrected by using polynomial fitting. Melting curves for the DNA conjugates were measured in a Perkin-Elmer Lambda 12 $\mathrm{UV} / \mathrm{Vis}$ spectrophotometer at $280 \mathrm{~nm}$ while the temperature was raised from 20 to $80^{\circ} \mathrm{C}$ at a rate of $1.0^{\circ} \mathrm{C} \mathrm{min}^{-1}$. Curve fits were excellent, with $\chi^{2}$ values of $10^{-6}$ or better, and the Van't Hoff linear fits were quite good $\left(r^{2}=0.98\right)$ for all oligonucleotides. Differences of less than $10 \%$ were observed between thermodynamic parameters as determined by $1 / T_{m}$ versus $\ln [$ conjugate] plots and curve fittings. $\Delta \mathrm{H}, \Delta \mathrm{S}$, and $\Delta \mathrm{G}$ errors were calculated as described previously.[20]

\section{Preparation of carbohydrate alcohols and phosphoramidites.}

2-Hydroxyethyl-2,3,4-tri- $\boldsymbol{O}$-acetyl- $\boldsymbol{\beta}$-I-fucopyranoside (20): $\mathrm{Na}_{2} \mathrm{SO}_{4}$ (7 spatula tips) and ethylene glycol $(2.0 \mathrm{~mL}, 35.86 \mathrm{mmoL}, 18$ equiv) were added to a solution of tri- $O$ acetylfucopyranosyl bromide $(0.68 \mathrm{~g}, 1.93 \mathrm{mmol})$ in anhydrous $\mathrm{CH}_{2} \mathrm{Cl}_{2}(40 \mathrm{~mL})$. After the mixture had been stirred at room temperature for 15 min under an argon atmosphere, $\mathrm{Ag}_{2} \mathrm{CO}_{3}(9.00 \mathrm{~g}, 16.31 \mathrm{mmol}, 8.5$ equiv) was added to the reaction mixture and stirring was continued for $18 \mathrm{~h}$ (TLC: hexane (Hex)/EtOAc 2:3). The mixture was filtered, diluted with $\mathrm{CH}_{2} \mathrm{Cl}_{2}(40 \mathrm{~mL})$, washed with water $(3 \times 100 \mathrm{~mL})$, and dried over anhydrous $\mathrm{MgSO}_{4}$; the solvent was then evaporated under reduced pressure. The product was purified by silica gel column chromatography by using Hex/EtOAc (2:3) as the eluent to give compound 20 (0.4 g, 62\%) as a syrup. ${ }^{1} \mathrm{H}$ NMR $\left(300 \mathrm{MHz}, \mathrm{CDCl}_{3}\right): \delta=5.19\left(\mathrm{dd},{ }^{3} J(\mathrm{H}, \mathrm{H})=0.5,3.0 \mathrm{~Hz}, 1 \mathrm{H}\right.$; H4), $5.14\left(\mathrm{dd},{ }^{3} J(\mathrm{H}, \mathrm{H})=7.8,10.5 \mathrm{~Hz}, 1 \mathrm{H} ; \mathrm{H} 2\right), 4.98\left(\mathrm{dd},{ }^{3} J(\mathrm{H}, \mathrm{H})=3.3,10.5 \mathrm{~Hz}, 1 \mathrm{H} ; \mathrm{H} 3\right)$, $4.44\left(\mathrm{~d},{ }^{3} J(\mathrm{H}, \mathrm{H})=7.8 \mathrm{~Hz}, 1 \mathrm{H} ; \mathrm{H1}\right), 3.84-3.66(\mathrm{~m}, 5 \mathrm{H} ; \mathrm{H} 5,2 \times \mathrm{H} 7,2 \mathrm{xH} 8), 2.64$ (br s, 1H; 
$\mathrm{OH}), 2.14,2.04,1.94\left(3 \mathrm{~s}, 9 \mathrm{H} ; 3 \mathrm{xOCOCH}_{3}\right), 1.19 \mathrm{ppm}\left(\mathrm{d},{ }^{3} \mathrm{~J}(\mathrm{H}, \mathrm{H})=6.3 \mathrm{~Hz}, 3 \mathrm{H} ; \mathrm{CH}_{3}\right) ;{ }^{13} \mathrm{C}$ $\operatorname{NMR}\left(75 \mathrm{MHz}, \mathrm{CDCl}_{3}\right): \mathrm{d}=170.4,169.9,169.6,101.2,71.9,70.9,69.9,68.9,68.7,61.4$, 20.5, 20.4, 20.3, 15.7 ppm; FAB HRMS: m/z: calcd for $\mathrm{C}_{14} \mathrm{H}_{22} \mathrm{O}_{9}: 334.1264[\mathrm{M}]^{+}$; found: $357.1167[\mathrm{M}+\mathrm{Na}]^{+}$.

2-Hydroxyethyl-3,4,6-tri- $O$-acetyl-2-deoxy- $\alpha, \beta$-D-glucopyranoside $(23,24)$ : A solution of $\mathrm{PPh}_{3} \cdot \mathrm{HBr}(0.71 \mathrm{~g}, 2.07 \mathrm{mmoL})$ and ethylene glycol in dry $\mathrm{CH}_{2} \mathrm{Cl}_{2}(25 \mathrm{~mL})$ was added to a solution of tri- $O$-acetyl-glucal $(7.5 \mathrm{~g}, 27.5 \mathrm{mmoL})$ in dry $\mathrm{CH}_{2} \mathrm{Cl}_{2}(8 \mathrm{~mL})$. The reaction mixture was stirred at $40^{\circ} \mathrm{C}$. After $24 \mathrm{~h}$, more $\mathrm{PPh}_{3} \cdot \mathrm{HBr}(2.13 \mathrm{~g}, 6.21 \mathrm{mmoL})$ was added to the reaction mixture, and stirring was continued for $7 \mathrm{~h}$. The reaction was then stopped by addition of $\mathrm{CH}_{2} \mathrm{Cl}_{2}(120 \mathrm{~mL})$ and water $(150 \mathrm{~mL})$. The organic phase was washed with saturated $\mathrm{NaHCO}_{3}(3 \mathrm{~T} 150 \mathrm{~mL})$, dried over anhydrous $\mathrm{Na}_{2} \mathrm{SO}_{4}$, and filtered; the solvent was then evaporated to dryness. The final product was purified by silica gel column chromatography by using a solvent gradient (Hex/EtOAc 5:4, 1:1, 4:5, 2:3) to obtain $\beta$ isomer $\mathbf{2 3}(460 \mathrm{mg}, 5 \%), \alpha$ isomer $\mathbf{2 4}(1.84 \mathrm{~g}, 20 \%)$, and a fraction mixture of $\mathbf{2 3}$ and $\mathbf{2 4}$ (1.38 g, 15\%). ${ }^{1} \mathrm{H}$ NMR (300 MHz, $\left.\mathrm{CDCl}_{3}\right): \beta$ isomer 23: $\delta=5.03-4.86(\mathrm{~m}, 2 \mathrm{H} ; \mathrm{H} 3, \mathrm{H} 4)$, $4.58\left(\mathrm{~d},{ }^{3} J(\mathrm{H}, \mathrm{H})=9.6 \mathrm{~Hz}, 1 \mathrm{H} ; \mathrm{H} 1\right), 4.18\left(\mathrm{dd},{ }^{3} J(\mathrm{H}, \mathrm{H})=5.6,{ }^{2} J(\mathrm{H}, \mathrm{H})=12.2 \mathrm{~Hz}, 1 \mathrm{H} ; \mathrm{H} 6 \mathrm{a}\right), 4.12$ $\left(\mathrm{t},{ }^{2} J(\mathrm{H}, \mathrm{H})=11.7 \mathrm{~Hz}, 1 \mathrm{H} ; \mathrm{H} 6 \mathrm{~b}\right), 3.82-3.59(\mathrm{~m}, 5 \mathrm{H} ; \mathrm{H} 5,2 \mathrm{xH} 7,2 \mathrm{xH} 8), 2.74\left(\mathrm{t},{ }^{3} J(\mathrm{H}, \mathrm{H})=6.1\right.$ $\mathrm{Hz}, 1 \mathrm{H} ; \mathrm{OH}), 2.32\left(\mathrm{dd},{ }^{3} J(\mathrm{H}, \mathrm{H})=4.7,{ }^{2} J(\mathrm{H}, \mathrm{H})=12.5 \mathrm{~Hz}, 1 \mathrm{H} ; \mathrm{H} 2_{\mathrm{eq}}\right), 2.05,2.00,1.99(3 \mathrm{~s}, 9 \mathrm{H}$; $3 \mathrm{xOCOCH} 3), 1.72 \mathrm{ppm}\left(\mathrm{q},{ }^{2} J(\mathrm{H}, \mathrm{H})=11.0 \mathrm{~Hz}, 1 \mathrm{H} ; \mathrm{H} 2 \mathrm{ax}\right) ;{ }^{13} \mathrm{C} \mathrm{NMR}\left(75 \mathrm{MHz}, \mathrm{CDCl}_{3}\right): \beta$ isomer 23: $\delta=170.6,170.2,169.7,100.1,72.7,71.9,70.3,68.9,62.4,62.0,36.0,20.8,20.6$ ppm; FAB HRMS: $\beta$ isomer 23: m/z: calcd for $\mathrm{C}_{14} \mathrm{H}_{22} \mathrm{O}_{9}: 334.1264$ [M] ${ }^{+}$; found: 357.1165 $[\mathrm{M}+\mathrm{Na}]^{+} .{ }^{1} \mathrm{H}$ NMR $\left(300 \mathrm{MHz}, \mathrm{CDCl}_{3}\right): \alpha$ isomer 24: $\delta=5.25\left(\mathrm{ddd},{ }^{3} J(\mathrm{H}, \mathrm{H})=5.3,9.5,11.5\right.$ $\mathrm{Hz}, 1 \mathrm{H}$; H3) 4.96-4.89 (m, 2H; H1, H4), $4.94\left(\mathrm{dd},{ }^{3} J(\mathrm{H}, \mathrm{H})=4.5,{ }^{2} J(\mathrm{H}, \mathrm{H})=12.4 \mathrm{~Hz}, 1 \mathrm{H}\right.$; 
H6a), $4.00\left(\mathrm{dd},{ }^{3} J(\mathrm{H}, \mathrm{H})=2.2,{ }^{2} J(\mathrm{H}, \mathrm{H})=12.3 \mathrm{~Hz}, 1 \mathrm{H} ; \mathrm{H} 6 \mathrm{~b}\right), 4.01-3.92(\mathrm{~m}, 1 \mathrm{H} ; \mathrm{H} 5), 3.70$ 3.64 (m, 3H; H7a, 2xH8), 3.54-3.47 (m, 1H; H7b), 2.7 (br s, 1H; OH), 2.22 (dd, $\left.{ }^{3} J(\mathrm{H}, \mathrm{H})=5.3,{ }^{2} J(\mathrm{H}, \mathrm{H})=12.9 \mathrm{~Hz}, 1 \mathrm{H} ; \mathrm{H} 2_{\mathrm{eq}}\right), 2.02,1.97,1.95\left(3 \mathrm{~s}, 9 \mathrm{H} ; 3 \mathrm{xOCOCH}_{3}\right), 1.77$ ppm $\left(\mathrm{dt}, 1 \mathrm{H},{ }^{3} J(\mathrm{H}, \mathrm{H})=3.6,{ }^{2} J(\mathrm{H}, \mathrm{H})=12.9 \mathrm{~Hz} ; \mathrm{H} 2 \mathrm{ax}\right) ;{ }^{13} \mathrm{C} \mathrm{NMR}\left(75 \mathrm{MHz}, \mathrm{CDCl}_{3}\right): \alpha$ isomer 24: $d=170.4,170.0,169.6,96.9,69.1,69.0,68.7,67.6,62.0,61.1,34.6,20.6,20.4,20.3$ ppm; FAB HRMS: m/z: a isomer 24: calcd for $\mathrm{C}_{14} \mathrm{H}_{22} \mathrm{O}_{9}: 334.1264$ [M] $]^{+}$; found: 357.1167 $[\mathrm{M}+\mathrm{Na}]^{+}$.

$\beta$-Cyanoethoxy- $\beta$-(2,3,4,6-tetra- $O$-acetyl- $\beta$-D-glucopyranosyl)ethoxy-diisopropylamine phosphine (15): DIEA $(0.49 \mathrm{~mL}, 3.72 \mathrm{mmol})$ and 2-cyanoethyl- $N, N^{\prime}$-diisopropylaminochlorophosphoramidite (170 $\mu \mathrm{L}, 0.76 \mathrm{mmoL})$ were added to a solution of 2-hydroxyethyl2,3,4,6-tetra- $O$-acetyl- $\beta$-D-glucopyranoside $(\mathbf{1 4} ;[17] \quad 0.2 \mathrm{~g}, 0.51 \mathrm{mmol})$ in anhydrous $\mathrm{CH}_{2} \mathrm{Cl}_{2}(4 \mathrm{~mL})$ at room temperature under an argon atmosphere. After $1.5 \mathrm{~h}$, the solution was diluted with EtOAc $(20 \mathrm{~mL})$, and the organic phase was washed with brine $(3 \times 25 \mathrm{~mL})$, dried over anhydrous $\mathrm{MgSO}_{4}$, and filtered; the solvent was then evaporated to dryness. The product was purified by silica gel column chromatography by using Hex/EtOAc (2:1 with $2 \%$ of $\mathrm{NEt}_{3}$ ) as the eluent to give compound $\mathbf{1 5}(215 \mathrm{mg}, 74 \%)$ as a syrup. ${ }^{1} \mathrm{H}$ NMR (300 $\left.\mathrm{MHz}, \mathrm{CDCl}_{3}\right)$ : mixture of isomers: $\delta=5.11\left(\mathrm{t},{ }^{3} \mathrm{~J}(\mathrm{H}, \mathrm{H})=9.4 \mathrm{~Hz}, 1 \mathrm{H} ; \mathrm{H} 3\right), 4.99(\mathrm{t}$, $\left.{ }^{3} J(\mathrm{H}, \mathrm{H})=9.6 \mathrm{~Hz}, 1 \mathrm{H} ; \mathrm{H} 4\right), 4.89\left(\mathrm{t},{ }^{3} J(\mathrm{H}, \mathrm{H})=8.0 \mathrm{~Hz}, 1 \mathrm{H} ; \mathrm{H} 2\right), 4.55\left(\mathrm{t},{ }^{3} J(\mathrm{H}, \mathrm{H})=8.6 \mathrm{~Hz}, 1 \mathrm{H}\right.$; H1), $4.18\left(\mathrm{dd},{ }^{3} J(\mathrm{H}, \mathrm{H})=2.6,{ }^{2} J(\mathrm{H}, \mathrm{H})=12.1 \mathrm{~Hz}, 1 \mathrm{H} ; \mathrm{H6a}\right), 4.06-3.99(\mathrm{~m}, 1 \mathrm{H} ; \mathrm{H} 6 \mathrm{~b}), 3.89-$ $3.45\left(\mathrm{~m}, 9 \mathrm{H} ; \quad \mathrm{H} 5,2 \mathrm{xH} 7,2 \mathrm{xH} 8, \quad \mathrm{OCH}_{2} \mathrm{CH}_{2} \mathrm{CN}, 2 \mathrm{xCHisopropyl}\right), 2.56(\mathrm{~m}, 2 \mathrm{H}$; $\left.\mathrm{OCH}_{2} \mathrm{CH}_{2} \mathrm{CN}\right), 1.99,1.97,1.96,1.93,1.91\left(5 \mathrm{~s}, 12 \mathrm{H} ; 4 x \mathrm{OCOCH}_{3}\right), 1.09 \mathrm{ppm}(2 \mathrm{~d}$, ${ }^{3} J(\mathrm{H}, \mathrm{H})=6.2 \mathrm{~Hz}, 12 \mathrm{H} ; 4 \mathrm{xCH} 3$ isopropyl $) ;{ }^{13} \mathrm{C} \mathrm{NMR}(75 \mathrm{MHz}, \mathrm{CDCl} 3)$ : mixture of isomers: $\delta=170.4,170.0,169.2,169.1,169.1,117.6,100.6,72.6,72.6,72.5,71.5,71.0,69.4,69.3$ 
$69.2,69.1,68.1,68.1,62.4,62.3,62.2,62.1,61.7,60.1,58.4,58.3,58.1,58.0,42.9,42.9$, 42.8, 42.7, 24.4, 24.4, 24.3, 24.3, 20.8, 20.5, 20.4, 20.2, 20.2, 20.1, 20.1 ppm; FAB HRMS: m/z: calcd for $\mathrm{C}_{25} \mathrm{H}_{41} \mathrm{~N}_{2} \mathrm{O}_{12} \mathrm{P}: 592.2397[\mathrm{M}]^{+}$; found: $615.2294[\mathrm{M}+\mathrm{Na}]^{+}$.

\section{$\beta$-Cyanoethoxy- $\beta$-(2,3,4,6-tetra- $O$-acetyl- $\beta$-D-galactopyranosyl)ethoxy-diisopropyl-}

amine phosphine (18): DIEA (0.96 mL, $3.72 \mathrm{mmol})$ and 2-cyanoethyl- $N, N^{\prime}-$ diisopropylamino-chlorophosphoramidite $(332 \mu \mathrm{L}, 1.49 \mathrm{mmoL})$ were added to a solution of 2-hydroxyethyl-2,3,4,6-tetra- $O$-acetyl- $\beta$-D-galactopyranoside $(\mathbf{1 7} ;[17] 0.39 \mathrm{~g}, 0.99 \mathrm{mmol})$ in dry $\mathrm{CH} 2 \mathrm{Cl} 2(4 \mathrm{~mL})$ at room temperature under an argon atmosphere. After $1.5 \mathrm{~h}$, the solution was diluted with EtOAc $(20 \mathrm{~mL})$, and the organic phase was washed with brine ( $3 \times 25 \mathrm{~mL}$ ), dried over anhydrous $\mathrm{MgSO}_{4}$, and filtered; the solvent was then evaporated to dryness. The product was purified by silica gel column chromatography by using Hex/EtOAc (2:3 with $2 \%$ of $\mathrm{NEt}_{3}$ ) as the eluent to give compound $\mathbf{1 8}(368 \mathrm{mg}, 84 \%)$ as a syrup. ${ }^{1} \mathrm{H}$ NMR $\left(300 \mathrm{MHz}, \mathrm{CDCl}_{3}\right)$ : mixture of isomers: $\delta=5.32\left(\mathrm{~d},{ }^{3} J(\mathrm{H}, \mathrm{H})=2.9 \mathrm{~Hz}, 1 \mathrm{H}\right.$; H4), $5.13\left(\mathrm{ddd},{ }^{3} J(\mathrm{H}, \mathrm{H})=2.2,8.0,10.3 \mathrm{~Hz}, 1 \mathrm{H} ; \mathrm{H} 2\right), 4.95\left(\mathrm{dt},{ }^{3} J(\mathrm{H}, \mathrm{H})=3.6,10.3 \mathrm{~Hz}, 1 \mathrm{H}\right.$; H3), $4.53\left(\mathrm{t},{ }^{3} J(\mathrm{H}, \mathrm{H})=7.5 \mathrm{~Hz}, 1 \mathrm{H} ; \mathrm{H1}\right), 4.15-4.01$ (m, 2H; 2xH6), 3.95-3.45 (m, 9H; H5, $\left.2 \mathrm{xH} 7,2 \mathrm{xH} 8, \mathrm{OCH}_{2} \mathrm{CH}_{2} \mathrm{CN}, 2 \mathrm{xCHisopropyl}\right), 2.59\left(\mathrm{t},{ }^{3} \mathrm{~J}(\mathrm{H}, \mathrm{H})=6.1 \mathrm{~Hz}, 2 \mathrm{H} ; \mathrm{OCH}_{2} \mathrm{CH}_{2} \mathrm{CN}\right)$, 2.09, 2.01, 2.00, 1.94, $1.91\left(5 \mathrm{~s}, 12 \mathrm{H} ; 4 \mathrm{xOCOCH}_{3}\right), 1.12 \mathrm{ppm}\left(2 \mathrm{~d},{ }^{3} J(\mathrm{H}, \mathrm{H})=6.5 \mathrm{~Hz}, 12 \mathrm{H}\right.$; $4 \mathrm{xCH} 3$ isopropyl); ${ }^{13} \mathrm{C}$ NMR (75 MHz, $\mathrm{CDCl}_{3}$ ): mixture of isomers: $\delta=170.2,170.1,170.0$, 169.3, 117.6, 101.1, 101.0, 70.7, 70.4, 69.4, 69.3, 69.1, 69.0, 68.6, 68.5, 66.9, 66.8, 62.4, $62.3,62.2,62.1,61.1,61.0,58.4,58.3,58.1,58.1,43.0,42.9,42.8,24.5,24.4,24.4,24.3$, 20.7, 20.5, 20.5, 20.4, 20.3, 20.3, 20.2, $20.2 \mathrm{ppm}$; FAB HRMS: m/z: calcd for $\mathrm{C}_{25} \mathrm{H}_{41} \mathrm{~N}_{2} \mathrm{O}_{12} \mathrm{P}: 592.2397[\mathrm{M}]^{+}$; found: $592.2397[\mathrm{M}+\mathrm{Na}]^{+}$. 


\section{$\beta$-Cyanoethoxy- $\beta$-(2,3,4,-tri- $O$-acetyl-l-fucopyranosyl)ethoxy-diisopropylamine}

phosphine (21): DIEA $(0.51 \mathrm{~mL}, 2.92 \mathrm{mmol})$ and 2-cyanoethyl- $N, N^{\prime}$-diisopropylaminochlorophosphoramidite ( $260 \mu \mathrm{L}, 1.18 \mathrm{mmoL}$ ) were added to a solution of 2-hydroxyethyl2,3,4-tri- $O$-acetyl- $\beta$-L-fucopyranoside $(\mathbf{2 0} ; 0.26 \mathrm{~g}, 0.78 \mathrm{mmol})$ in dry $\mathrm{CH}_{2} \mathrm{Cl}_{2}(4 \mathrm{~mL})$ at room temperature under an argon atmosphere. After $1.5 \mathrm{~h}$, the solution was diluted with EtOAc $(20 \mathrm{~mL})$, and the organic phase was washed with brine $(3 \times 25 \mathrm{~mL})$, dried over anhydrous $\mathrm{MgSO}_{4}$, and filtered; the solvent was then evaporated to dryness. The product was purified by silica gel column chromatography by using Hex/EtOAc (2:1 with $2 \% \mathrm{NEt}_{3}$ ) as the eluent to give compound 21 as a syrup (200 mg, 48\%). ${ }^{1} \mathrm{H}$ NMR (300 MHz, $\mathrm{CDCl}_{3}$ ): mixture of isomers: $\delta=5.18\left(\mathrm{~d},{ }^{3} J(\mathrm{H}, \mathrm{H})=3.3 \mathrm{~Hz}, 1 \mathrm{H} ; \mathrm{H} 4\right), 5.13\left(\mathrm{ddd},{ }^{3} \mathrm{~J}(\mathrm{H}, \mathrm{H})=2.4,7.9,10.4\right.$ $\mathrm{Hz}, 1 \mathrm{H} ; \mathrm{H} 2), 4.96\left(\mathrm{dt},{ }^{3} J(\mathrm{H}, \mathrm{H})=3.8,10.4 \mathrm{~Hz}, 1 \mathrm{H} ; \mathrm{H} 3\right), 4.51\left(\mathrm{~m},{ }^{3} J(\mathrm{H}, \mathrm{H})=8.3 \mathrm{~Hz}, 1 \mathrm{H} ; \mathrm{H} 1\right)$, 3.98-3.48 (m, 9H; H5, 2xH7, 2xH8, $\mathrm{OCH}_{2} \mathrm{CH}_{2} \mathrm{CN}, 2$ CHisopropyl), $2.60\left(\mathrm{t},{ }^{3} \mathrm{~J}(\mathrm{H}, \mathrm{H})=6.3\right.$ $\left.\mathrm{Hz}, 1 \mathrm{H} ; \mathrm{OCH}_{2} \mathrm{CH}_{2} \mathrm{CN}\right), 2.13,2.03,2.02,1.93\left(4 \mathrm{~s}, 9 \mathrm{H} ; 3 \mathrm{xOCOCH}_{3}\right), 1.18\left(\mathrm{~d},{ }^{3} J(\mathrm{H}, \mathrm{H})=6.3\right.$,

$\left.3 \mathrm{H} ; \mathrm{CH}_{3}\right), 1.14 \mathrm{ppm}\left(2 \mathrm{~d},{ }^{3} \mathrm{~J}(\mathrm{H}, \mathrm{H})=6.7 \mathrm{~Hz}, 12 \mathrm{H} ; 4 \mathrm{xCH}_{3}\right.$ isopropyl $) ;{ }^{13} \mathrm{C}$ NMR $(75 \mathrm{MHz}$, $\mathrm{CDCl}_{3}$ ): mixture of isomers: $\delta=170.6,170.1,169.4,117.7,101.0,100.9,71.2,71.2,70.2$, $70.1,69.3,69.2,69.0,69.0,68.9,68.8,68.7,62.5,62.4,62.3,62.2,58.5,58.2,43.0,43.0$, 42.9, 42.8, 24.5, 24.5, 24.4, 20.8, 20.8, 20.6, 20.5, 20.3, 20.3, 15.9 ppm; FAB HRMS: m/z: calcd for $\mathrm{C}_{23} \mathrm{H}_{41} \mathrm{~N}_{2} \mathrm{O}_{10} \mathrm{P}: 534.2342[\mathrm{M}]^{+}$; found: $557.2240[\mathrm{M}+\mathrm{Na}]^{+}$.

\section{$\beta$-Cyanoethoxy- $\beta$-(3,4,6-tri- $O$-acetyl-2-deoxy- $\beta$-D-glucopyranosyl)ethoxydiisopropyl-}

amine phosphine (25): DIEA (0.39 mL, $2.24 \mathrm{mmol})$ and 2-cyanoethyl- $N, N^{\prime}$ diisopropylamino-chlorophosphoramidite ( $200 \mu \mathrm{L}, 0.9 \mathrm{mmoL})$ were added to a solution of 2-hydroxyethyl-2,3,4-tri- $O$-acetyl-2-deoxy- $\beta$-D-glucopyranoside $(\mathbf{2 3} ; 0.2 \mathrm{~g}, 0.6 \mathrm{mmol})$ in anhydrous $\mathrm{CH}_{2} \mathrm{Cl}_{2}(4 \mathrm{~mL})$ at room temperature under an argon atmosphere. After $1.5 \mathrm{~h}$, the 
solution was diluted with EtOAc $(20 \mathrm{~mL})$, and the organic phase was washed with brine (3x25 mL), dried over anhydrous $\mathrm{MgSO}_{4}$, and filtered; the solvent was then evaporated to dryness. The product was purified by silica gel column chromatography by using Hex/EtOAc (2:1 with $2 \%$ of $\mathrm{NEt}_{3}$ ) as the eluent to give compound $25(284 \mathrm{mg}, 89 \%)$ as a syrup. ${ }^{1} \mathrm{H}$ NMR $\left(300 \mathrm{MHz}, \mathrm{CDCl}_{3}\right)$ : mixture of isomers: $\delta=4.98-4.79(\mathrm{~m}, 2 \mathrm{H} ; \mathrm{H} 3, \mathrm{H} 4)$, $4.56\left(\mathrm{~d},{ }^{3} J(\mathrm{H}, \mathrm{H})=9.4 \mathrm{~Hz}, 1 \mathrm{H} ; \mathrm{H} 1\right), 4.19\left(\mathrm{dd},{ }^{3} J(\mathrm{H}, \mathrm{H})=4.4,{ }^{2} J(\mathrm{H}, \mathrm{H})=12.1 \mathrm{~Hz}, 1 \mathrm{H} ; \mathrm{H} 6 \mathrm{a}\right)$, 4.06-3.92 (m, 1H; H6b), 3.92-3.40 (m, 9H; H5, 2xH7, 2xH8, $\mathrm{OCH}_{2} \mathrm{CH}_{2} \mathrm{CN}$, 2xCHisopropyl), $2.56\left(\mathrm{t},{ }^{3} J(\mathrm{H}, \mathrm{H})=6.2 \mathrm{~Hz}, 2 \mathrm{H} ; \mathrm{OCH}_{2} \mathrm{CH}_{2} \mathrm{CN}\right), 2.22\left(\mathrm{dd},{ }^{3} J(\mathrm{H}, \mathrm{H})=4.4,{ }^{2} J\right.$ $\left.(\mathrm{H}, \mathrm{H})=10.0 \mathrm{~Hz}, 1 \mathrm{H} ; \mathrm{H} 2_{\mathrm{eq}}\right), 1.97,1.92,1.91\left(3 \mathrm{~s}, 9 \mathrm{H} ; 3 \times \mathrm{OCOCH}_{3}\right), 1.71-1.53 \mathrm{ppm}(\mathrm{m}, 1 \mathrm{H}$; $\left.\mathrm{H} 2_{\mathrm{ax}}\right) ;{ }^{13} \mathrm{C} \mathrm{NMR}\left(75 \mathrm{MHz}, \mathrm{CDCl}_{3}\right)$ : mixture of isomers: $\delta=170.4,170.0,169.9,169.5$, $117.5,99.5,99.4,71.6,71.6,70.3,69.1,69.0,68.8,68.7,62.4,62.3,62.1,58.4,58.3,58.1$, 42.9, 42.7, 35.9, 24.4, 24.4, 24.3, 20.7, 20.6, 20.5 ppm; FAB HRMS: m/z: calcd for $\mathrm{C}_{25} \mathrm{H}_{39} \mathrm{~N}_{2} \mathrm{O}_{10} \mathrm{P}: 534.2342[\mathrm{M}]^{+}$; found: $557.2240[\mathrm{M}+\mathrm{Na}]^{+}$.

\section{$\beta$-Cyanoethoxy- $\beta$-(3,4,6-tri-O-acetyl-2-deoxy- $\alpha$-D-glucopyranosyl)ethoxydiisopropyl-}

aminophosphine (26): DIEA (0.59 mL, $3.38 \mathrm{mmol})$ and 2-cyanoethyl- $N, N^{\prime}-$ diisopropylamino-chlorophosphoramidite $(0.3 \mathrm{~mL}, 1.35 \mathrm{mmol})$ were added to a solution of 2-hydroxyethyl-2,3,4-tri- $O$-acetyl-2-deoxy- $\alpha$-D-glucopyranoside $(\mathbf{2 4} ; 0.3 \mathrm{~g}, 0.9 \mathrm{mmol})$ in dry $\mathrm{CH}_{2} \mathrm{Cl}_{2}(4 \mathrm{~mL})$ at room temperature under an argon atmosphere. After $1 \mathrm{~h}$, the solution was diluted with EtOAc $(20 \mathrm{~mL})$, and the organic phase was washed with brine $(3 \times 25 \mathrm{~mL})$, dried over anhydrous $\mathrm{MgSO}_{4}$, and filtered; the solvent was then evaporated to dryness. The product was purified by silica gel column chromatography by using Hex/EtOAc (3:2 with $2 \%$ of $\left.\mathrm{NEt}_{3}\right)$ as the eluent to give compound $26(410 \mathrm{mg}, 85 \%)$ as a syrup. ${ }^{1} \mathrm{H}-\mathrm{NMR}$ (300 $\left.\mathrm{MHz}, \mathrm{CDCl}_{3}\right)$ : mixture of isomers: $\mathrm{d}=5.33-5.36(\mathrm{~m}, 1 \mathrm{H} ; \mathrm{H} 3), 5.02-4.88(\mathrm{~m}, 2 \mathrm{H} ; \mathrm{H} 1, \mathrm{H} 4)$, 
$4.25\left(\mathrm{dd},{ }^{3} J(\mathrm{H}, \mathrm{H})=4.4,{ }^{2} J(\mathrm{H}, \mathrm{H})=12.3 \mathrm{~Hz}, 1 \mathrm{H} ; \mathrm{H} 6 \mathrm{a}\right), 4.08-3.91$ (m, 2H; H5, H6b), 3.91-3.65 (m, 5H; H7a, 2xH8, $\left.\mathrm{OCH}_{2} \mathrm{CH}_{2} \mathrm{CN}\right), 3.65-3.44(\mathrm{~m}, 3 \mathrm{H} ; \mathrm{H} 7 \mathrm{~b}, 2 \mathrm{xCHisopropyl}), 2.63(\mathrm{t}$, $\left.{ }^{3} J(\mathrm{H}, \mathrm{H})=6.2 \mathrm{~Hz}, 2 \mathrm{H} ; \mathrm{OCH}_{2} \mathrm{CH}_{2} \mathrm{CN}\right), 2.20\left(\mathrm{dd},{ }^{3} J(\mathrm{H}, \mathrm{H})=5.2, J(\mathrm{H}, \mathrm{H})=12.8 \mathrm{~Hz}, 1 \mathrm{H} ; \mathrm{H} 2 \mathrm{eq}\right)$, $2.04,1.98,1.95(3 \mathrm{~s}, 9 \mathrm{H} ; 3 \mathrm{xOCOCH} 3), 1.76\left(\mathrm{dt},{ }^{3} J(\mathrm{H}, \mathrm{H})=3.0,{ }^{2} J(\mathrm{H}, \mathrm{H})=12.2 \mathrm{~Hz}, 1 \mathrm{H}\right.$; $\mathrm{H} 2 \mathrm{ax}), 1.14 \mathrm{ppm}\left(\mathrm{d},{ }^{3} J(\mathrm{H}, \mathrm{H})=6.7 \mathrm{~Hz}, 12 \mathrm{H} ; 4 \mathrm{xCH} \mathrm{CH}_{3}\right.$ isopropyl $) ;{ }^{13} \mathrm{C} \mathrm{NMR}\left(75 \mathrm{MHz}, \mathrm{CDCl}_{3}\right)$ : mix of isomers: $\delta=170.7,170.7,170.2,169.9,117.7,97.1,97.0,69.3,69.3,69.1,69.0$, $67.9,67.8,67.6,67.5,67.4,62.5,62.4,62.3,62.2,58.6,58.4,43.2,43.1,24.7,24.6,21.0$, 20.8, 20.7, 20.4, 20.3 ppm; FAB HRMS: m/z: calcd for $\mathrm{C}_{23} \mathrm{H}_{39} \mathrm{~N}_{2} \mathrm{O}_{10} \mathrm{P}: 534.2342[\mathrm{M}]^{+}$; found: $573.2120[\mathrm{M}+\mathrm{K}]^{+}$.

1-Hydroxyethyl- $\beta$-D-glucopyranoside (8): $\mathrm{NaOMe}(27 \mathrm{mg}, 0.50 \mathrm{mmol})$ was added to a solution of 2-hydroxyethyl-2,3,4,6-tetra- $O$-acetyl- $\beta$-D-glucopyranoside $(\mathbf{1 4} ; 100 \mathrm{mg}, 0.25$ mmol) in $\mathrm{MeOH}(3 \mathrm{~mL})$, and the reaction was stirred at room temperature for $30 \mathrm{~min}$. The solution was then neutralized with Amberlite IRA-120 resin and filtered, and the solvent was eliminated in vacuo to obtain compound 8 (56 mg, quant yield) as a white solid. ${ }^{1} \mathrm{H}$ NMR (500 MHz, D2O): d=4.49 (d, $\left.{ }^{3} J(\mathrm{H}, \mathrm{H})=7.9 \mathrm{~Hz}, 1 \mathrm{H} ; \mathrm{H1}\right), 3.98(\mathrm{~m}, 1 \mathrm{H} ; \mathrm{H} 7 \mathrm{a}), 3.91$ (dd, $\left.{ }^{3} J(\mathrm{H}, \mathrm{H})=2.2,12.3 \mathrm{~Hz}, 1 \mathrm{H} ; \mathrm{H} 6 \mathrm{~b}\right), 3.77(\mathrm{~m}, 3 \mathrm{H} ; \mathrm{H} 7 \mathrm{~b}, 2 \mathrm{TH} 8) 3.72\left(\mathrm{dd},{ }^{3} J(\mathrm{H}, \mathrm{H})=6.0,12.3 \mathrm{~Hz}\right.$, 1H; H6a), $3.50\left(\mathrm{t},{ }^{3} J(\mathrm{H}, \mathrm{H})=9.2 \mathrm{~Hz}, 1 \mathrm{H} ; \mathrm{H} 3\right), 3.45(\mathrm{~m}, 1 \mathrm{H} ; \mathrm{H} 5), 3.39\left(\mathrm{t},{ }^{3} J(\mathrm{H}, \mathrm{H})=9.4 \mathrm{~Hz}\right.$, $1 \mathrm{H} ; \mathrm{H} 4), 3.31 \mathrm{ppm}\left(\mathrm{dd},{ }^{3} J(\mathrm{H}, \mathrm{H})=8.0,9.4 \mathrm{~Hz}, 1 \mathrm{H} ; \mathrm{H} 6 \mathrm{~b}\right) ;{ }^{13} \mathrm{C} \mathrm{NMR}\left(100 \mathrm{MHz}, \mathrm{CD}_{3} \mathrm{OD}\right)$ : $\delta=103.1,76.6,76.5,73.8,71.0,70.2,61.3,60.9 \mathrm{ppm} ;$ ESIMS: $\mathrm{m} / \mathrm{z}$ : calcd for $\mathrm{C}_{25} \mathrm{H}_{41} \mathrm{~N}_{2} \mathrm{O}_{12} \mathrm{P}: 592.2397[\mathrm{M}]^{+}$; found: $592.2397[\mathrm{M}+\mathrm{Na}]^{+}$.

1-Hydroxyethyl- $\beta$-D -galactopyranoside (9): $\mathrm{NaOMe}(27 \mathrm{mg}, 0.50 \mathrm{mmol})$ was added to a solution of 2-hydroxyethyl-2,3,4,6-tetra- $O$-acetyl- $\beta$-D-galactopyranoside $(\mathbf{1 7} ; 100 \mathrm{mg}, 0.25$ $\mathrm{mmol})$ in $\mathrm{MeOH}(3 \mathrm{~mL})$, and the reaction was stirred at room temperature for $30 \mathrm{~min}$. The 
solution was then neutralized with Amberlite IRA-120 resin and filtered, and the solvent was eliminated in vacuo to obtain compound 9 (56 mg, quant yield) as a white solid. ${ }^{1} \mathrm{H}$ NMR (500 MHz, D $2 \mathrm{O}): \mathrm{d}=4.42\left(\mathrm{~d},{ }^{3} J(\mathrm{H}, \mathrm{H})=7.8 \mathrm{~Hz}, 1 \mathrm{H} ; \mathrm{H} 1\right), 4.05$ (m, 1H; H7a), 3.92 (d, $\left.{ }^{3} J(\mathrm{H}, \mathrm{H})=3.4 \mathrm{~Hz}, 1 \mathrm{H} ; \mathrm{H} 4\right), 3.81-3.75(\mathrm{~m}, 4 \mathrm{H} ; \mathrm{H} 6 \mathrm{a}, \mathrm{H} 7 \mathrm{~b}, 2 \mathrm{xH} 8), 3.74\left(\mathrm{dd},{ }^{3} J(\mathrm{H}, \mathrm{H})=4.2,11.7\right.$ $\mathrm{Hz}, 1 \mathrm{H} ; \mathrm{H} 6 \mathrm{~b}), 3.70\left(\mathrm{dd},{ }^{3} J(\mathrm{H}, \mathrm{H})=4.2,8.0 \mathrm{~Hz}, 1 \mathrm{H} ; \mathrm{H} 5\right), 3.65\left(\mathrm{dd},{ }^{3} J(\mathrm{H}, \mathrm{H})=3.5,10.8 \mathrm{~Hz}, 1 \mathrm{H}\right.$; H3), $3.55 \mathrm{ppm}\left(\mathrm{dd},{ }^{3} J(\mathrm{H}, \mathrm{H})=7.9,10.0 \mathrm{~Hz}, 1 \mathrm{H} ; \mathrm{H} 2\right) ;{ }^{13} \mathrm{C}-\mathrm{NMR}\left(100 \mathrm{MHz}, \mathrm{CD}_{3} \mathrm{OD}\right)$ : $\delta=103.8,75.3,73.5,71.3,70.0,68.9,61.1,61.0$ ppm; ESIMS: m/z: calcd for $\mathrm{C}_{8} \mathrm{H}_{16} \mathrm{O}_{7}$ : $224.1[\mathrm{M}]^{+}$; found: $247.1[\mathrm{M}+\mathrm{Na}]^{+}$.

1-Hydroxyethyl- $\beta$-l-fucopyranoside (10): NaOMe $(32 \mathrm{mg}, 0.60 \mathrm{mmol})$ was added to a solution of 2-hydroxyethyl-2,3,4-tri- $O$-acetyl- $\beta$-L-fucopyranoside $(\mathbf{2 0} ; 100 \mathrm{mg}, 0.30 \mathrm{mmol})$ in $\mathrm{MeOH}(3 \mathrm{~mL})$, and the reaction was stirred at room temperature for $30 \mathrm{~min}$. The solution was then neutralized with Amberlite IRA-120 resin and filtered, and the solvent was eliminated in vacuo to obtain compound 10 (53 mg, 86\%) as a white solid. ${ }^{1} \mathrm{H}$ NMR (500 $\left.\mathrm{MHz}, \mathrm{D}_{2} \mathrm{O}\right): \delta=4.90\left(\mathrm{~d},{ }^{3} J(\mathrm{H}, \mathrm{H})=7.9 \mathrm{~Hz}, 1 \mathrm{H} ; \mathrm{H} 1\right), 3.98(\mathrm{~m}, 1 \mathrm{H} ; \mathrm{H} 7 \mathrm{a}), 3.90(\mathrm{dd}$, $\left.{ }^{3} J(\mathrm{H}, \mathrm{H})=6.5,7.6 \mathrm{~Hz}, 1 \mathrm{H} ; \mathrm{H} 7 \mathrm{~b}\right) 3.77(\mathrm{~m}, 1 \mathrm{H} ; \mathrm{H} 5), 3.76(\mathrm{~m}, 2 \mathrm{H} ; 2 \mathrm{xH} 8) 3.74(\mathrm{~m}, 1 \mathrm{H} ; \mathrm{H} 4)$, $3.64\left(\mathrm{dd},{ }^{3} J(\mathrm{H}, \mathrm{H})=3.5,10.0 \mathrm{~Hz}, 1 \mathrm{H} ; \mathrm{H} 3\right), 3.50\left(\mathrm{dd},{ }^{3} J(\mathrm{H}, \mathrm{H})=7.9,10.0 \mathrm{~Hz}, 1 \mathrm{H} ; \mathrm{H} 2\right), 1.25$ $\operatorname{ppm}\left(\mathrm{d},{ }^{3} J(\mathrm{H}, \mathrm{H})=6.5 \mathrm{~Hz}, 1 \mathrm{H} ; \mathrm{CH}_{3}\right) ;{ }^{13} \mathrm{C} \mathrm{NMR}\left(100 \mathrm{MHz}, \mathrm{CD}_{3} \mathrm{OD}\right): \delta=103.6,73.6,71.6$, 71.0, 70.8, 70.6, 61.0, 15.3 ppm; ESIMS: m/z: calcd for $\mathrm{C}_{8} \mathrm{H}_{16} \mathrm{O}_{7}: 208.1[\mathrm{M}]^{+}$; found: 231.1 $[\mathrm{M}+\mathrm{Na}]^{+}$.

1-Hydroxyethyl-2-deoxy- $\boldsymbol{\beta}$-D-glucopyranoside (11): NaOMe (16 mg, $0.30 \mathrm{mmol})$ was added to a solution of 2-hydroxyethyl-2,3,4-tri- $O$-acetyl-2-deoxy- $\beta$-D-glucopyranoside (23; $50 \mathrm{mg}, 0.15 \mathrm{mmol})$ in $\mathrm{MeOH}(2 \mathrm{~mL})$, and the reaction was stirred at room temperature for 30 min. The solution was then neutralized with Amberlite IRA-120 resin and filtered, and 
the solvent was eliminated in vacuo to obtain compound $\mathbf{1 1}$ (31 mg, quant yield) as a white solid. ${ }^{1} \mathrm{H}$ NMR $\left(500 \mathrm{MHz}, \mathrm{D}_{2} \mathrm{O}\right): \delta=4.74\left(\mathrm{dd},{ }^{3} J(\mathrm{H}, \mathrm{H})=1.5,9.8 \mathrm{~Hz}, 1 \mathrm{H} ; \mathrm{H} 1\right), 3.96(\mathrm{~m}, 1 \mathrm{H}$; H7) $3.92\left(\mathrm{dd},{ }^{3} J(\mathrm{H}, \mathrm{H})=2.3,12.3 \mathrm{~Hz}, 1 \mathrm{H}\right.$; H6b), 3.74 (m, 4H; H6a, H7b, 2xH8) 3.71 (dd, $\left.{ }^{3} J(\mathrm{H}, \mathrm{H})=1.5,9.8 \mathrm{~Hz}, 1 \mathrm{H} ; \mathrm{H} 4\right), 3.38\left(\mathrm{ddd},{ }^{3} J(\mathrm{H}, \mathrm{H})=2.0,6.5,9.0 \mathrm{~Hz}, 1 \mathrm{H} ; \mathrm{H} 5\right), 3.26(\mathrm{t}$, $\left.{ }^{3} J(\mathrm{H}, \mathrm{H})=9.6 \mathrm{~Hz}, 1 \mathrm{H} ; \mathrm{H} 4\right), 2.29\left(\mathrm{ddd},{ }^{3} J(\mathrm{H}, \mathrm{H})=1.8,4.6,{ }^{2} J(\mathrm{H}, \mathrm{H})=12.1 \mathrm{~Hz}, 1 \mathrm{H} ; \mathrm{H} 2 \mathrm{eq}\right), 1.52$ ppm $\left(\mathrm{dt},{ }^{3} J(\mathrm{H}, \mathrm{H})=10.6,{ }^{2} J(\mathrm{H}, \mathrm{H})=12.1 \mathrm{~Hz}, 1 \mathrm{H} ; \mathrm{H} 2_{\mathrm{ax}}\right) ;{ }^{13} \mathrm{C} \mathrm{NMR}\left(100 \mathrm{MHz}, \mathrm{CD}_{3} \mathrm{OD}\right)$ : $\delta=100.0,76.6,71.7,71.2,70.5,61.5,61.0,38.9$ ppm; ESIMS: m/z: calcd for $\mathrm{C}_{8} \mathrm{H}_{16} \mathrm{O}_{6}$ : $208.1[\mathrm{M}]^{+}$; found: $231.1[\mathrm{M}+\mathrm{Na}]^{+}$.

1-Hydroxyethyl-2-deoxy- $\boldsymbol{\alpha}$-D-glucopyranoside (12): NaOMe (16 mg, $0.30 \mathrm{mmol})$ was added to a solution of 2-hydroxyethyl-2,3,4-tri- $O$-acetyl-2-deoxy- $\alpha$-D-glucopyranoside (24; $50 \mathrm{mg}, 0.15 \mathrm{mmol})$ in $\mathrm{MeOH}(2 \mathrm{~mL})$, and the reaction was stirred at room temperature for 30 min. The solution was then neutralized with Amberlite IRA-120 resin and filtered, and the solvent was eliminated in vacuo to obtain compound $\mathbf{1 2}$ (31 mg, quant yield) as a white solid. ${ }^{1} \mathrm{H}$ NMR $\left(500 \mathrm{MHz}, \mathrm{D}_{2} \mathrm{O}\right): \delta=4.74\left(\mathrm{dd},{ }^{3} \mathrm{~J}(\mathrm{H}, \mathrm{H})=1.5,9.8 \mathrm{~Hz}, 1 \mathrm{H} ; \mathrm{H} 1\right), 3.96(\mathrm{~m}, 1 \mathrm{H}$; H7) $3.92\left(\mathrm{dd},{ }^{3} J(\mathrm{H}, \mathrm{H})=2.3,12.3 \mathrm{~Hz}, 1 \mathrm{H}\right.$; H6b), 3.74 (m, 4H; H6a, H7b, 2TH8) 3.71 (dd, $\left.{ }^{3} J(\mathrm{H}, \mathrm{H})=1.5,9.8 \mathrm{~Hz}, 1 \mathrm{H} ; \mathrm{H} 4\right), 3.38\left(\mathrm{ddd},{ }^{3} J(\mathrm{H}, \mathrm{H})=2.0,6.5,9.0 \mathrm{~Hz}, 1 \mathrm{H} ; \mathrm{H} 5\right), 3.26(\mathrm{t}$, $\left.{ }^{3} J(\mathrm{H}, \mathrm{H})=9.6 \mathrm{~Hz}, 1 \mathrm{H} ; \mathrm{H} 4\right), 2.29\left(\mathrm{ddd},{ }^{3} J(\mathrm{H}, \mathrm{H})=1.8,4.60,{ }^{2} J(\mathrm{H}, \mathrm{H})=12.1 \mathrm{~Hz}, 1 \mathrm{H} ; \mathrm{H} 2 \mathrm{eq}\right), 1.52$ ppm $\left(\mathrm{dt},{ }^{3} J(\mathrm{H}, \mathrm{H})=10.6,{ }^{3} J(\mathrm{H}, \mathrm{H})=12.1 \mathrm{~Hz}, 1 \mathrm{H} ; \mathrm{H} 2{ }_{\mathrm{ax}}\right) ;{ }^{13} \mathrm{C} \mathrm{NMR}\left(100 \mathrm{MHz}, \mathrm{CD}_{3} \mathrm{OD}\right)$ : $\delta=100.0,76.6,71.7,71.2,70.5,61.5,61.0,38.9$ ppm; ESIMS: m/z: calcd for $\mathrm{C}_{8} \mathrm{H}_{16} \mathrm{O}_{6}$ : $208.1[\mathrm{M}]^{+}$; found: $231.1[\mathrm{M}+\mathrm{Na}]^{+}$.

Synthesis of carbohydrate-oligonucleotide conjugates 1-7: Carbohydrateoligonucleotide conjugates were synthesized on an Applied Biosystems 394 synthesizer by using standard $\beta$-cyanoethylphosphoramidite chemistry. The benzene DMT- 
phosphoramidite derivative was prepared as previously described.[16] Oligonucleotide conjugates were synthesized on a 0.2 or $1.0 \mu \mathrm{mol}$ scale low-volume resin and in DMT-off mode. DMTethane phosphoramidite was purchased from Chemgenes Corp. Oligonucleotide supports were treated with $33 \%$ aqueous ammonia for $16 \mathrm{~h}$ at $55^{\circ} \mathrm{C}$, then the ammonia solutions were evaporated to dryness and the conjugates were purified by reversed-phase HPLC in a Waters Alliance separation module with a PDA detector. HPLC conditions were as follows: Nucleosil $120 \mathrm{C} 18,250 \times 8 \mathrm{~mm} 10 \mu \mathrm{m}$ column; flow rate: 3 $\mathrm{mLmin}^{-1} ; 27$ min linear gradient $0-30 \% \mathrm{~B}$ (solvent A: $5 \% \quad \mathrm{CH}_{3} \mathrm{CN} / 95 \% 100 \mathrm{mM}$ triethylammonium acetate (TEAA; $\mathrm{pH}$ 6.5); solvent B: 70\% $\mathrm{CH}_{3} \mathrm{CN} / 30 \% 100 \mathrm{mM}$ TEAA $(\mathrm{pH} 6.5))$

\section{Acknowledgements}

We thank the Ministry of Science and Education for funding (grant no.: CTQ-200601123/BQU) and for a Ramón y Cajal contract (J.C.M.).

\section{References}

[1] a) T. Feizi, Adv. Exp. Med. Biol. 1998, 435, 51; b) R. A. Dwek, Chem. Rev. 1996, 96, 683; c) A. Varki, Glycobiology 1993, 3, 97; d) H. J. Gabius, H. C. Siebert, S. Andre, J. Jimenez-Barbero, H. Rudiger, ChemBioChem 2004, 5, 740.

[2] R. U. Lemieux, Acc. Chem. Res. 1996, 29, 373.

[3] a) A. B. Boraston, D. N. Bolam, H. J. Gilbert, G. J. Davies, Biochem. J. 2004, 382, 769;

b) H. Kogelberg, D. Solis, J. Jimenez-Barbero, Curr. Opin. Struct. Biol. 2003, 13, 646; c) H. Lis, N. Sharon, Chem. Rev. 1998, 98, 637. 
[4] a) M. C. Fernandez-Alonso, F. J. Canada, J. Jimenez-Barbero, G. Cuevas, J. Am. Chem.

Soc. 2005, 127, 7379; b) M. S. Sujatha, Y. U. Sasidhar, P. V. Balaji, Biochemistry 2005, 44, 9554; c) V. Spiwok, P. Lipovova, T. Skalova, E. Buchtelova, J. Hasek, B. Kralova, Carbohydr. Res. 2004, 339, 2275; d) S. Elgavish, B. Shaanan, Trends Biochem. Sci. 1997, 22, 462; e) E. J. Toone, Curr. Opin. Struct. Biol. 1994, 4, 719.

[5] a) J. Flint, D. Nurizzo, S. E. Harding, E. Longman, G. J. Davies, H. J. Gilbert, D. N. Bolam, J. Mol. Biol. 2004, 337, 417; b) L. Guan, Y. Hu, H. R. Kaback, Biochemistry 2003, 42, 1377; c) M. Kasahara, M. Maeda, J. Biol. Chem. 1998, 273, 29106; d) K. Maenaka, M. Matsushima, H. Song, F. Sunada, K. Watanabe, I. Kumagai, J. Mol. Biol. 1995, 247, 281.

[6] G. Terraneo, D. Potenza, A. Canales, J. Jimenez-Barbero, K. K. Baldridge, A. Bernardi, J. Am. Chem. Soc. 2007, 129, 2890.

[7] J. Screen, E. C. Stanca-Kaposta, D. P. Gamblin, B. Liu, N. A. Macleod, L. C. Snoek, B. G. Davis, J. P. Simons, Angew. Chem. 2007, 119, 3718; Angew. Chem. Int. Ed. 2007, 46, 3644.

[8] R. Palma, M. E. Himmel, J. W. Brady, J. Phys. Chem. B 2000, 104, 7228.

[9] a) J. C. Morales, S. PenadUs, Angew. Chem. 1998, 110, 673; Angew. Chem. Int. Ed. 1998, 37, 654; b) K. Kobayashi, Y. Asakawa, Y. Kato, Y. Aoyama, J. Am. Chem. Soc. $1992,114,10307$.

[10] a) A. P. Davis, R. S. Wareham, Angew. Chem. 1999, 111, 3160; Angew. Chem. Int. Ed. 1999, 38, 2978; b) M. Mazik, H. Cavga, P. G. Jones, J. Am. Chem. Soc. 2005, 127, 9045.

[11] Y. Ferrand, M. P. Crump, A. P. Davis, Science 2007, 318, 619.

[12] K. Piotukh, V. Serra, R. Borriss, A. Planas, Biochemistry 1999, 38, 16092.

[13] S. E. Kiehna, Z. R. Laughrey, M. L. Waters, Chem. Commun. 2007, 4026. 
[14] a) M. Senior, R. A. Jones, K. J. Breslauer, Biochemistry 1988, 27, 3879; b) S.

Bommarito, N. Peyret, J. SantaLucia, Jr., Nucleic Acids Res. 2000, 28, 1929.

[15] a) E. T. Kool, J. C. Morales, K. M. Guckian, Angew. Chem. 2000, 112, 1046; Angew. Chem. Int. Ed. 2000, 39, 990; b) K. M. Guckian, B. A. Schweitzer, R. X. F. Ren, C. J. Sheils, D. C. Tahmassebi, E. T. Kool, J. Am. Chem. Soc. 2000, 122, 2213; c) J. C. Morales, E. T. Kool, Biochemistry 2000, 39, 12979.

[16] a) U. Wichai, S. A. Woski, Org Lett. 1999, 1, 1173; b) S. Matsuda, F. E. Romesberg, J. Am. Chem. Soc. 2004, 126, 14419.

[17] B. L. Sorg, W. E. Hull, H.-C. Kliem, W. Mier, M. Wiessler, Carbohydr. Res. 2005, $340,181$.

[18] A. P. Rauter, S. Lucas, T. Almeida, D. Sacoto, V. Ribeiro, J. Justino, A. Neves, F. V. M. Silva, M. C. Oliveira, M. J. Ferreira, M.-S. Santos, E. Barbosa, Carbohydr. Res. 2005, 340, 191.

[19] M. Adinolfi, L. De Napoli, G. Di Fabio, A. Iadonisi, D. Montesarchio, G. Piccialli, Tetrahedron 2002, 58, 6697.

[20] a) M. Petersheim, D. H. Turner, Biochemistry 1983, 22, 256; b) T. Ohmichi, S. Nakano, D. Miyoshi, N. Sugimoto, J. Am. Chem. Soc. 2002, 124, 10367.

[21] S. Liu, X. Ji, G. L. Gilland, W. J. Stevens, R. N. Armstrong, J. Am. Chem. Soc. 1993, $115,7910$.

[22] a) L. K. Tsou, C. D. Tatko, M. L. Waters, J. Am. Chem. Soc. 2002, 124, 14917; b) E. Lacroix, A. R. Viguera, L. Serrano, J. Mol. Biol. 1998, 284, 173. 
Scheme 1 A. Dangling-ended DNA model system designed to measure carbohydratearomatic interactions. B. Enlarged view of the structure of the dangling-end area of the carbohydrate-oligonucleotide conjugate. C. Carbohydrate oligonucleotide conjugates included in the study. Oligonucleotide conjugate $\mathbf{1}$ is BCGCGCG, where B is the benzene nucleoside. In conjugates 2-7, DNA seq represents -OPO${ }_{2}^{-}$-BCGCGCG.

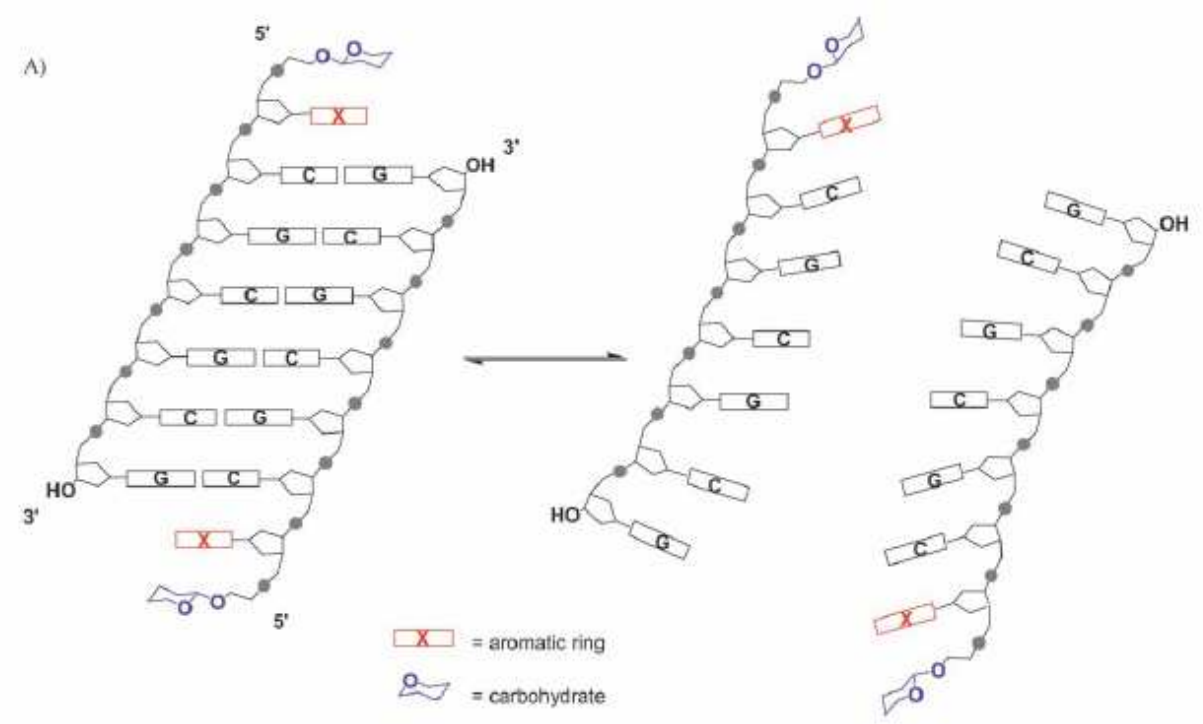

B)

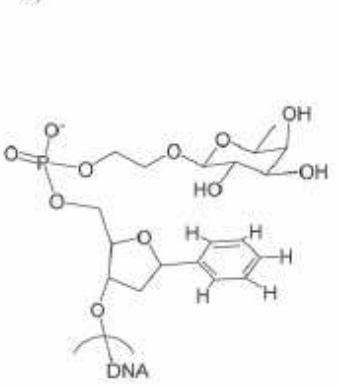

C)

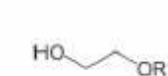

R-DNA seq 2

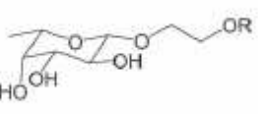

$R=D$ NA seq 5 $\mathrm{R}-\mathrm{H} \quad 10$

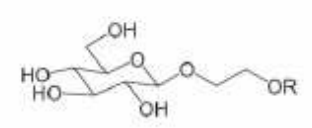

$\mathrm{R}=\mathrm{DNA}$ seq 3

$\mathrm{R}=\mathrm{H} \quad 8$

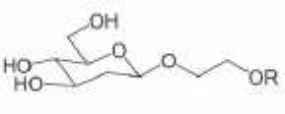

$R=$ DNA seq 6 $\mathrm{R}-\mathrm{H} \quad 11$

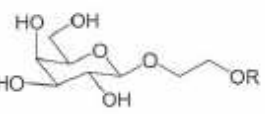

R-DNA seq 4

$\mathrm{R}-\mathrm{H} \quad 9$

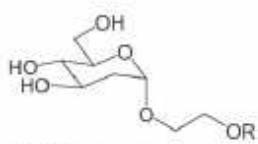

R=DNA seq 7

$\mathrm{R}-\mathrm{H} \quad 12$ 
Scheme 2. Synthetic routes used to prepare the carbohydrate phosphoramidite derivatives. (a) Ethyleneglycol, $\mathrm{Ag}_{2} \mathrm{CO}_{3}, \mathrm{CH}_{2} \mathrm{Cl}_{2}, \quad$ R.T., 18h, 28-62\%; (b) 2-cyanoethyl- $N, N$ 'diisopropylamino-chlorophosphoramidite, N,N-diisopropylethylamine (DIEA), $\mathrm{CH}_{2} \mathrm{Cl}_{2}$, R.T., 1.5h, 74-92\%; (c) ethyleneglycol, $\mathrm{PPh}_{3} \cdot \mathrm{HBr}, \mathrm{CH}_{2} \mathrm{Cl}_{2}$, R.T., 7h, 5\% of 23 and $20 \%$ of 24.

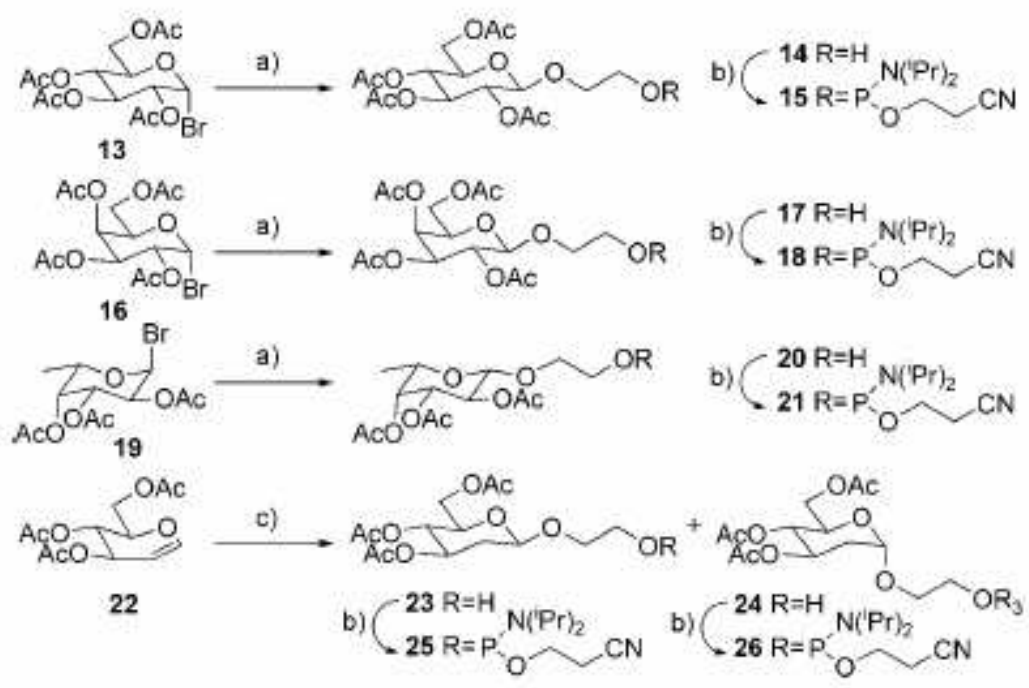

Table 1. Carbohydrate-aromatic stacking, as measured in a DNA-duplex context.

\begin{tabular}{rccccc}
\hline Dangling moiety $a$ & $\begin{array}{c}T m \\
\left({ }^{\circ} \mathrm{C}\right)\end{array}$ & $\begin{array}{c}-\Delta H^{\mathrm{o}} \\
(\mathrm{Kcal} / \mathrm{mol})\end{array}$ & $\begin{array}{c}-\Delta S^{\mathrm{o}} \\
(\mathrm{cal} / \mathrm{K} . \mathrm{mol})\end{array}$ & $\begin{array}{c}-\Delta G_{37}{ }^{\mathrm{o}} \\
(\mathrm{Kcal} / \mathrm{mol})\end{array}$ & $\begin{array}{c}\Delta \Delta G_{37} \\
\text { stacking } \\
(\mathrm{Kcal} / \mathrm{mol})\end{array}$ \\
\hline HO-C2- & 51.1 & 58.2 & 156 & 9.7 & - \\
$\beta$ B-D-Glc-C2- & 50.0 & 56.1 & 150 & 9.4 & - \\
$\beta$ B-D-Gal-C2- & 50.4 & 59.1 & 159 & 9.7 & -0.15 \\
$\beta$ B-L-Fuc-C2- & 51.8 & 67.4 & 185 & 10.1 & -0.40 \\
$\beta$ B-D-2-deoxy-Glc-C2- & 50.7 & 61.0 & 166 & 9.7 & -0.15 \\
$\alpha$-D-2-deoxy-Glc-C2- & 51.0 & 60.9 & 165 & 9.8 & -0.20 \\
\hline
\end{tabular}

a Core sequence is BCGCGCG, in which $\mathrm{B}$ is the benzene nucleoside. $\mathrm{C} 2$ - indicates $\mathrm{CH}_{2}-\mathrm{CH}_{2}$ $\mathrm{OPO}_{2}{ }^{-} \cdot{ }^{b}$ Melting temperatures, $\mathrm{Tm}$ was measured at $10 \mu \mathrm{M} \mathrm{COC}$ concentration. ${ }^{c}$ Estimated errors are $\pm 8 \%$ in $\Delta H, \pm 8 \%$ in $\Delta S, \pm 11 \%$ in $\Delta G_{37}{ }^{d} \Delta \Delta G_{37}$ stacking per carbohydrate-

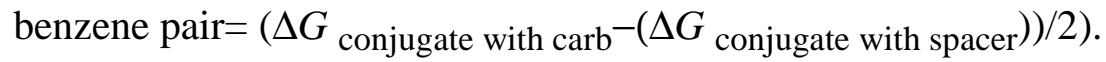


Figure 1. Model of the dangling-end area of carbohydrate-DNA conjugate 4, which contains a $\beta$-galactose unit. A) Possible stacking geometry of $\beta$-galactose on top of the benzene ring through the $\alpha$ face of the sugar. B) Possible stacking geometry of $\beta$-galactose on top of the benzene ring through the $\beta$ face of the sugar, with the steric clash between the 4-OH group and the arene shown
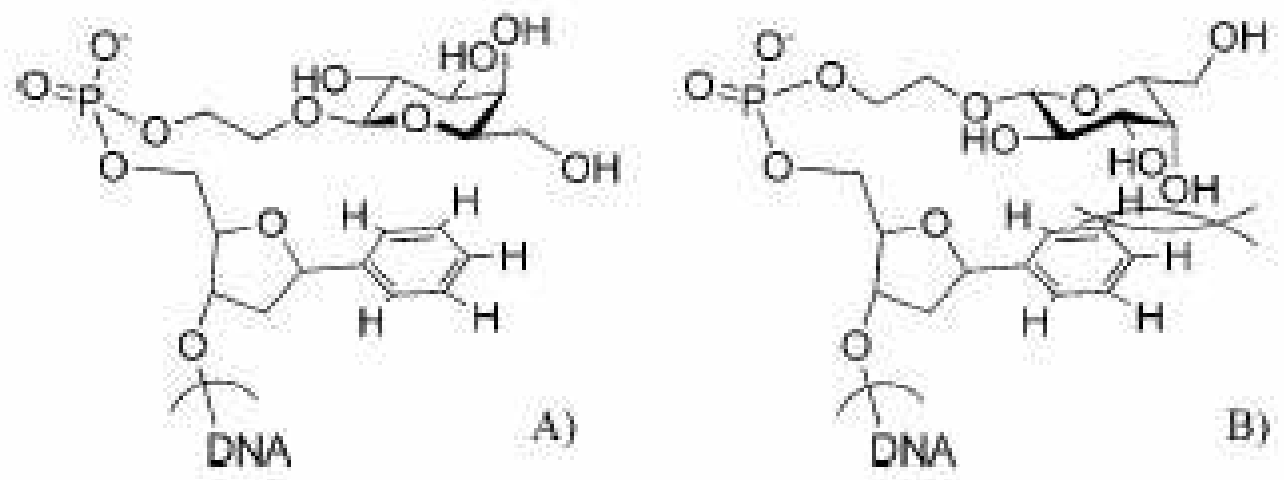
Table 2. ${ }^{1} \mathrm{H}$ NMR chemically induced shift differences between the sugar residues of the carbohydrate-oligonucleotide conjugates 3-7 and the corresponding monosaccaride controls 8-12 in $\mathrm{D}_{2} \mathrm{O}{ }^{[\mathrm{a}]}$

\begin{tabular}{|l|l|l|l|l|l|}
\hline & $\beta$-D-Glc & $\beta$-D-Gal & $\beta$-L-Fuc & $\beta$-D-2-deoxy-Glc & $\alpha$-D-2-deoxy-Glc \\
\hline H1 & -0.112 & -0.102 & -0.144 & -0.190 & -0.094 \\
\hline H2 & $-0-056$ & -0.059 & -0.084 & -0.163 & -0.100 \\
\hline H2b & - & - & - & -0.127 & -0.087 \\
\hline H3 & -0.074 & -0.087 & -0.082 & -0.149 & -0.071 \\
\hline H4 & -0.048 & -0.051 & -0.093 & -0.086 & $-0-074$ \\
\hline H5 & -0.120 & -0.116 & -0.178 & $-[b]$ & $-0.067-0.067$ \\
\hline H6 & -0.069 & $-0-058$ & - & $-[b]$ & $-[b]$ \\
\hline H6b & -0.086 & -0.050 & - & -0.118 & -0.092 \\
\hline CH 3 & - & - & -0.122 & - & - \\
\hline
\end{tabular}

${ }^{[\mathrm{a}]}$ Chemical-shift differences are given in $\mathrm{ppm} .{ }^{[\mathrm{b}]}$ Unassigned proton due to overlapping resonances. 
Figure 2. ${ }^{1} \mathrm{H}$ NMR spectra of carbohydrate-oligonucleotide conjugate 5 (bottom) and the corresponding monosaccharide control 10 (top) in $\mathrm{D}_{2} \mathrm{O}$ showing the chemical-shift differences for the protons of the $\beta$-1-fucose residue

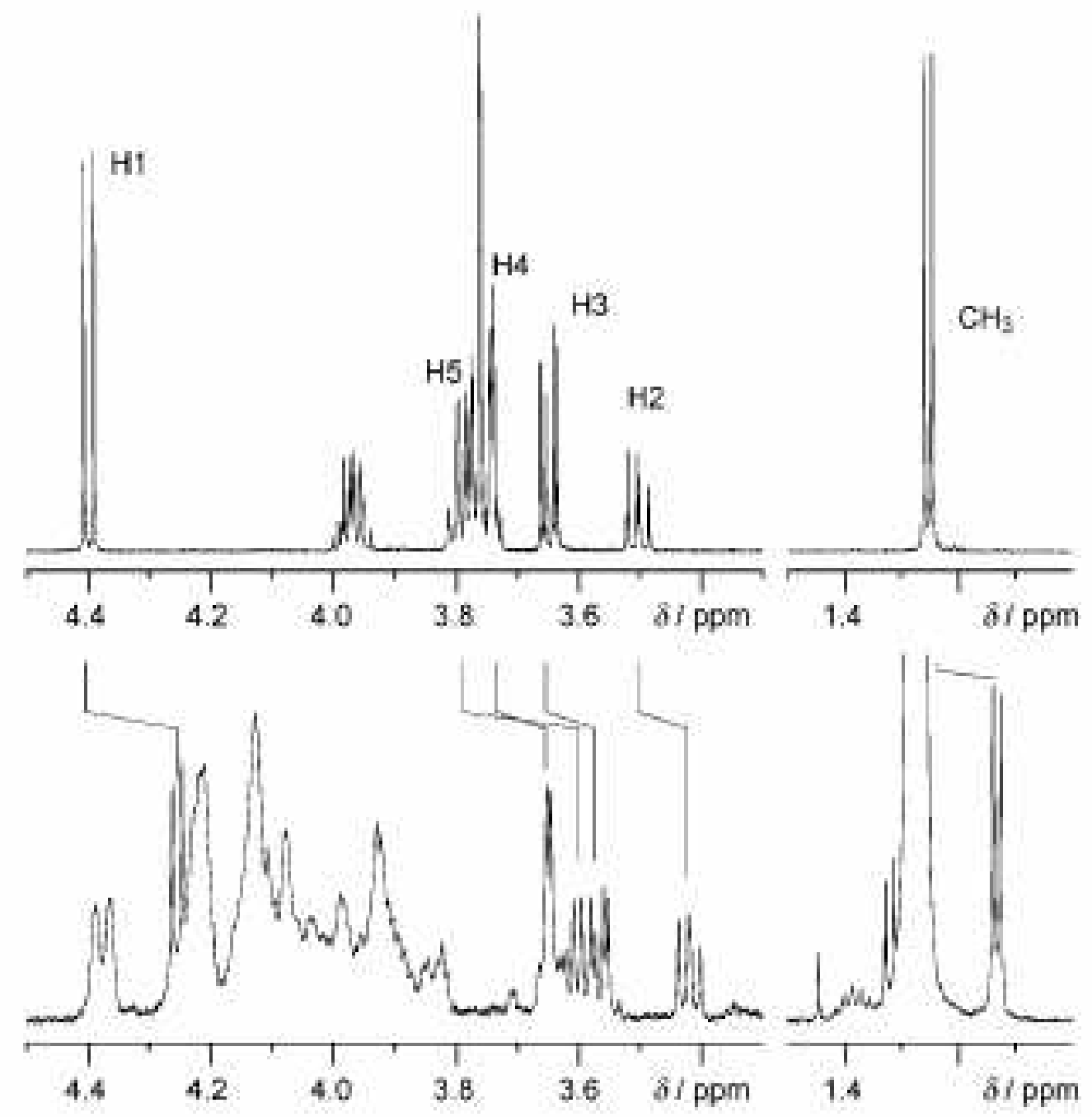


Figure 3. A) Upfield shifting of carbohydrate protons due to the proximity to the face of the aromatic ring. Differences are calculated between the conjugate containing $\beta$-D-glucose on the sequence BCGCGCG, 3, and 2-hydroxyethyl- $\beta$-D-glucopyranoside (8). B) Model of possible stacking geometry of $\beta$-glucose on top of the benzene ring through the $\alpha$ face of the sugar. C) Model of possible stacking geometry of $\beta$-glucose on top of the benzene ring through the $\beta$ face of the sugar.
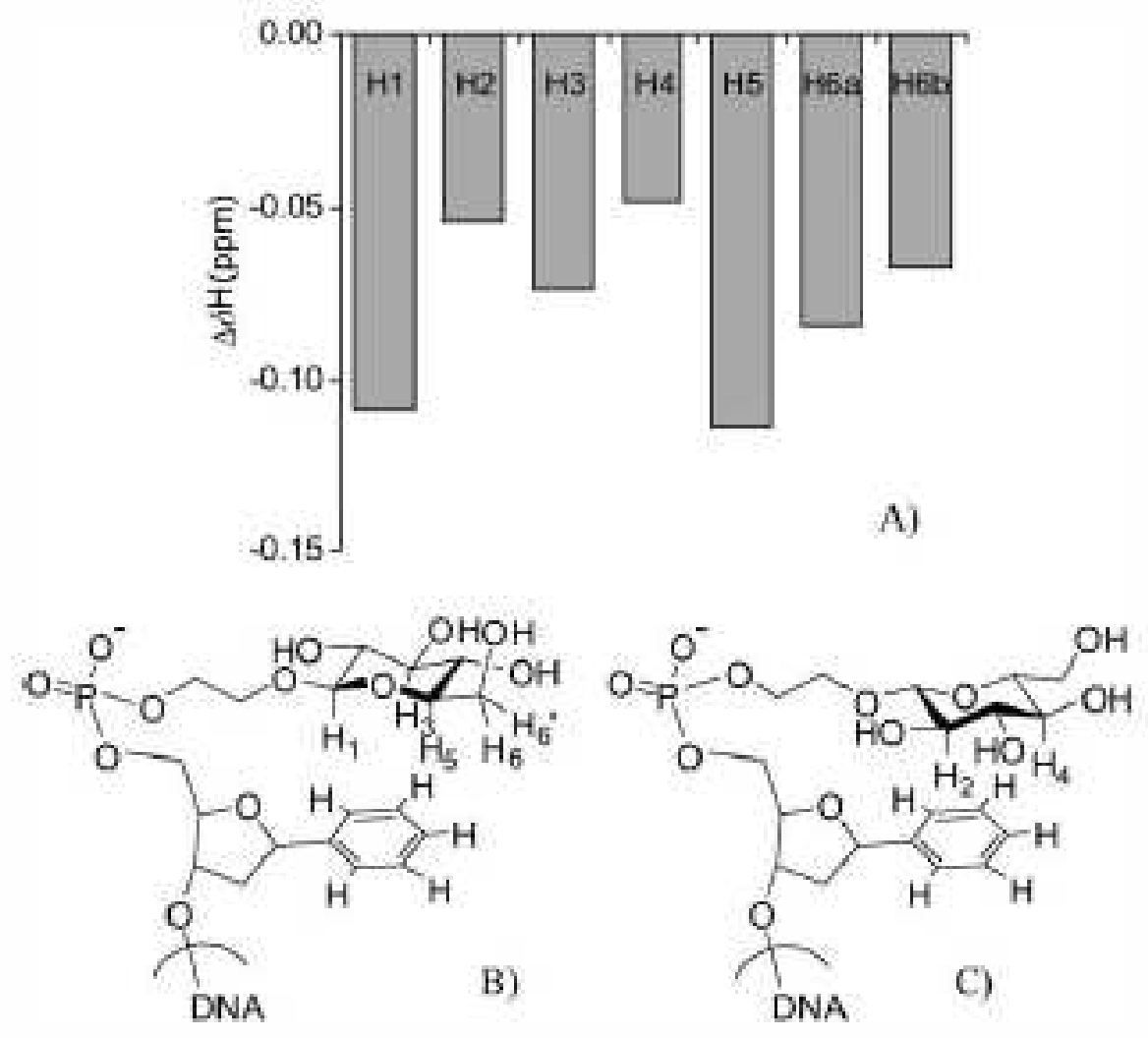